University for Business and Technology in Kosovo

UBT Knowledge Center

UBT International Conference

2013 UBT International Conference

Nov 2nd, 3:30 PM - 3:45 PM

\title{
Modified Sma Design Mix For Motorway Wearing Course - Case Study Kosovo Motorway
}

\author{
Esat Gashi \\ University of Prishtina, esat.gashi@uni-pr.edu \\ Hajdar Sadiku \\ University of Prishtina, hajdar.sadiku@uni-pr.edu
}

Follow this and additional works at: https://knowledgecenter.ubt-uni.net/conference

Part of the Architecture Commons

\section{Recommended Citation}

Gashi, Esat and Sadiku, Hajdar, "Modified Sma Design Mix For Motorway Wearing Course - Case Study Kosovo Motorway" (2013). UBT International Conference. 24.

https://knowledgecenter.ubt-uni.net/conference/2013/all-events/24

This Event is brought to you for free and open access by the Publication and Journals at UBT Knowledge Center. It has been accepted for inclusion in UBT International Conference by an authorized administrator of UBT Knowledge Center. For more information, please contact knowledge.center@ubt-uni.net. 


\title{
Modified Sma Design Mix For Motorway Wearing Course - Case Study Kosovo Motorway
}

\author{
Esat Gashi ${ }^{1}$, Hajdar Sadiku ${ }^{2}$ \\ Civil Engineering Faculty, University of Prishtina \& University for Business and Technology - \\ Prishtine \\ esat.gashi@uni-pr.edu ; esat.gashi@ubt-uni.net \\ ${ }^{2}$ Lecturer at the Civil Engineering Faculty University of Prishtina, \\ Department of road Infrastructure, \\ hajdar.sadiku@uni-pr.edu
}

\begin{abstract}
Stone Mastic Asphalt (SMA) mixtures rely on stone-to-stone contacts among particles to resist applied forces, and permanent deformation. Aggregates in SMA should resist degradation (fracture and abrasion) under high stresses at the contact points. For the Motorways, SMA stone grid must fulfil the Mineralogical-petro-graphic condition to be on rock of igneous and/or metamorphic origin but of silicate composition, specific weight and LA method on resistance to fragmentation. During the construction of the Kosovo motorway for wearing course was used the SMA as a asphalt layer providing longer lifetime to the road construction. During the Motorway construction the contractor was short of stone material with as specified in GTR material for wearing course, therefore it was compulsory to compose a new asphalt design mix with available rock in Kosovo. New quarry was explored in place called Golesh where stone extracted from this quarry have LA resistance on fragmentation lower than specifications allow for motorway. Specific weight of this stone is for $15 \%$ greater than ordinary stone used in laboratory design mix. For this specific stone were prepared special asphalt design mixtures with binder content $4.5 \%$ which was well below than typical SMA composition of $6.0-7.0 \%$ binder. During the asphalt paving some bitumen patches were noticed due to the specific weight of the stone in design mix, therefore it has been reduced vibration during the asphalt compaction. In this paperwork we will present design mixes with stone used from golesh quarry and results gained in laboratory and on site.
\end{abstract}

Key words: SMA design mix, stone grid, structural design , bitumen content, quality assurance, quality control

\section{Introduction}

Current practices for asphalt mix design and acceptance testing rely on volumetric properties. Vital to the calculation of mix volumetric properties are specific gravity measurements of the mixture and the aggregate in the mixture. In essence, the specific gravity measurements are conversion factors which allow conversion of mass percentages to volume proportions/percentages. By the nature of the materials used for construction, it is impossible to design a road pavement which does not deteriorate in some way with time and traffic, hence the aim of structural design is to limit the level of pavement distress, measured primarily in terms of riding quality, rut depth and cracking, to pre-determined values. Variability in material properties and construction control is always much greater than desired by the design engineer and must be taken into account explicitly in the design process. Only a very small percentage of the area of the surface of a road needs to show distress for the road to be considered unacceptable by road users.

The purpose of structuraldesign is to limit the stresses induces in the sub grade by traffic to a safe level at which sub grade deformation is insignificant whilst at the same time ensuring that the road pavement layers themselves do not deteriorate to any serious extent within specified period of time.

Each new structure initially need to be design and calculated, road structure as well, 


\section{Stone Mastic Asphalt Mixes}

Stone Mastic Asphalt is a high stiffness, high macro texture bituminous mixture suitable for use in high demand and/or high speed areas. The high macro texture compared with asphaltic concrete allows good surface drainage hence reducing the risk of aquaplaning, and also reduces traffic noise compared with chip seals or asphaltic concrete. International evidence has shown that Stone Mastic Asphalt resists the reflection of cracks in underlying layers as well. The process of designing a SMA mixture involves adjusting the grading to accommodate the required binder and void content rather than the more familiar process of adjusting the binder content to suit the aggregate grading.

Commonly used additives are fibres, such as cellulose fibres. Mastic is the mortar comprised of fines, filler, binder and stabilising additive, and may be modified with polymers to improve its rheological properties. The composition of the mastic mortar is a crucial factor contributing to the performance of Stone Mastic Asphalt. Bituminous binder shall be 60/70 penetration grade bitumen. Sufficient stabilis ing additives shall be added to the Stone Mastic Asphalt to ensure binder drainage does not occur during storage, transportation and construction. The design process for Stone Mastic Asphalt involves adjusting the grading to accommodate the required binder content (minimum of $6 \%$ to $7 \%$ depending on maximum aggregate particle size) and voids content rather than the traditional design process for other asphalt mixes, of adjusting the binder content to suit an aggregate gradation. Only crushed aggregates are specified for the Stone Mastic Asphalt to ensure suitable aggregate interlock. The use of natural aggregates containing polished or rounded particles, such as sand, is not permitted.

\subsection{Stone}

The use of certain types of stone in the pavement structure asphalt courses depends on the mineralogical and petrographic composition, the physical and mechanical properties and the granular stone materials production technology.

\subsection{Quality requirements}

Stone quality as raw material for production of granular stone material must full fill the conditions in order to be used for the asphalt pavements, some of the criterias are shown at the Table 3 .

\section{Asphalt Mix Design Properties}

Due to the fact that close to the Motorway site it was not available stone quarry with stone resistance to crushing LA $<16$ as it is requested by the EN standard for stones, it was taken in consideration to design a new asphalt mix using the stone granular fromthe quarry close to the Motorway (MIM Golesh quarry) with following to major characteristics:

\section{Stone resistance factor to crushing $\underline{\mathbf{L A}=\mathbf{1 8}}$ Density of stone material mix $\underline{\mathbf{0}} \underline{\mathbf{s m m}}=\underline{\mathbf{3 1 0 0} \mathbf{~ k g} / \mathbf{m}^{3}}$}

The new design asphalt mix was prepared with this stone for execution of wearing course of highway. Wearing course of highway was stone mastic asphalt of stone material with maximum ( nominal) particle size of $16 \mathrm{~mm}$ ( SMA $16 \mathrm{~mm}$ ). For new asphalt design mix were prepared 6 samples for initial job mix formula according to standard procedures.

Table 1. Composition and properties of designed asphalt mixtures.

\begin{tabular}{lllllll}
\hline & AM1 & AM2 & AM3 & AM4 & AM5 & AM6 \\
\hline Density of mixture FKM $\left[\mathrm{t} / \mathrm{m}^{3}\right]$ & 3,070 & 3,070 & 3,070 & 3,067 & 3,061 & 3,054 \\
Density AM $\left[\mathrm{t} / \mathrm{m}^{3}\right]$ & 2,829 & 2,863 & 2,881 & 2,816 & 2,818 & 2,820 \\
$\begin{array}{l}\text { Percentage of bitumen content } \\
\text { in AM [\%(m/m)] }\end{array}$ & 4,12 & 3,49 & 3,18 & 4,33 & 4,20 & 4,04 \\
\hline
\end{tabular}


Bitumen density: The density of bitumen used for preparation of asphalt mixtures and test specimen made according to Marshall Method ( EN 15326), Picknometer Method $\rho B=1,001\left(\mathrm{t} / \mathrm{m}^{3}\right)$. Bitumen type is

$\operatorname{PmB} 45 / 80$ - 65 ( Ex - Fis), and the bitumen content in asphalt mix design is $4.5 \%$.

Additives: used at the design mix were: Fibres , Arbocel ZZ 8/1 with share in design mix $0.4 \%$ and „Interflow $-\mathrm{T}$ ”, as chemical additive with share id design mix $0.6 \%$.

The final mix design for wearing course of highway with stone mastic asphalt of stone material with maximum ( nominal) particle size of $16 \mathrm{~mm}$ ( SMA $16 \mathrm{~mm}$ ) was accepted with following distribution See table 2.

Table 2. New mix design

\begin{tabular}{|c|c|c|c|c|}
\hline \multicolumn{5}{|c|}{ ASPHALT MIX DESIGN } \\
\hline Stone material & Aggregate fraction & $\begin{array}{l}\text { Share in } \\
{[\%(\mathrm{~m} / \mathrm{m})]}\end{array}$ & $\operatorname{mix}$ & Density $\left[\mathrm{t} / \mathrm{m}^{3}\right]$ \\
\hline Cement & Filler & 6.7 & & 3,000 \\
\hline Mim Golesh & $0-4$ & 21.6 & & 3,108 \\
\hline Mim Golesh & $4-8$ & 16.7 & & 3,107 \\
\hline Mim Golesh & $8-11$ & 18.5 & & 3,096 \\
\hline Mim Golesh & $11-16$ & 36.5 & & 3,120 \\
\hline \multicolumn{3}{|c|}{ Density of stone material $\left[\mathrm{t} / \mathrm{m}^{3}\right]$} & & 3,105 \\
\hline \multicolumn{3}{|c|}{ Type of bitumen } & & $\operatorname{PmB} 45 / 80-65$ \\
\hline \multicolumn{3}{|c|}{ Density of bitumen $\left[\mathrm{t} / \mathrm{m}^{3}\right]$} & & 1,012 \\
\hline \multicolumn{3}{|c|}{ Bitumen content in AM design } & & $4.5 \%$ \\
\hline \multicolumn{3}{|c|}{ Additive ; Fibres „Arbocel ZZ 8/1 } & & $0.4 \%$ \\
\hline \multicolumn{3}{|c|}{ „Interflow - T” } & & $0.6 \%$ \\
\hline
\end{tabular}

Table 3. Grain size distribution diagram

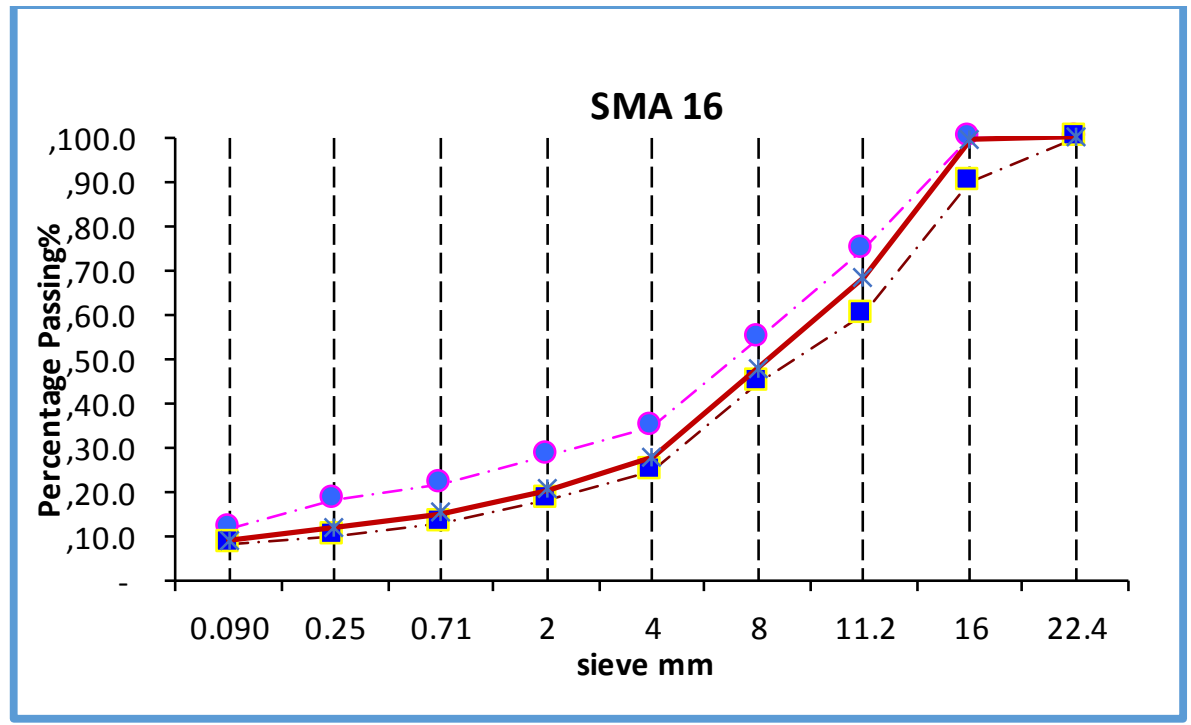

Table 4. Physical-mechanical properties an laboratory testing results for asphalt mixture Stone Mastic Asphalt SMA

\begin{tabular}{llllll}
\hline No. & Technical characteristics & $\begin{array}{l}\text { Test } \\
\text { standard }\end{array}$ & $\begin{array}{l}\text { Laboratory } \\
\text { Results }\end{array}$ & $\begin{array}{l}\text { Quality } \\
\text { conditions }\end{array}$ & $\begin{array}{l}\text { Category } \\
\text { EN 13108 }\end{array}$ \\
1(a) & $\begin{array}{l}\text { Void content, } \\
\text { Vmax }\end{array}$ & $\begin{array}{l}\text { EN 1\%] } 12697- \\
8\end{array}$ & 4.5 & $3-6$ & Vmax6 \\
& & & & & Vmin3 \\
\hline
\end{tabular}




\begin{tabular}{|c|c|c|c|c|c|c|c|}
\hline 2(a) & $\begin{array}{l}\text { Voids filled } \\
\text { with bitumen, } \\
\text { VFB max }\end{array}$ & {$[\%]$} & & & 73.8 & $71-83$ & VFBmax83 \\
\hline 3(a) & $\begin{array}{l}\text { Voids filled } \\
\text { with bitumen, } \\
\text { VFB min }\end{array}$ & {$[\%]$} & & & & & VFBmin 71 \\
\hline 4(b) & $\begin{array}{l}\text { Drained } \\
\text { material, D }\end{array}$ & {$[\%]$} & $\begin{array}{l}\mathrm{EN} \\
18\end{array}$ & $12697-$ & 0.11 & $\leq 0,6$ & $\mathrm{D} 0,6$ \\
\hline $5(\mathrm{c})$ & $\begin{array}{l}\text { Indirect tensile } \\
\text { ratio, ITSR [\%] }\end{array}$ & strength & $\begin{array}{l}\text { EN } 1 \\
12 \\
12697\end{array}$ & $\begin{array}{l}12697- \\
\text { EN } \\
7-23\end{array}$ & 86.93 & $\geq 80$ & ITSR80 \\
\hline $6(d)$ & $\begin{array}{l}\text { Wheel } \\
\text { tracking slope, } \\
\text { WTSAIR }\end{array}$ & {$[\%]$} & $\begin{array}{ll}\text { EN } & 1 \\
22\end{array}$ & $12697-$ & 0.038 & $\leq 0.07$ & $\begin{array}{l}\text { WTSAIR } \\
0.07\end{array}$ \\
\hline $7(d)$ & $\begin{array}{l}\text { Proportional } \\
\text { rut depth, } \\
\text { PRDAIR }\end{array}$ & {$[\%]$} & & & 4.63 & $\leq 5.0[\%]$ & PRDAIR5.0 \\
\hline 8(e) & Stiffness & {$[\mathrm{MPa}]$} & $\begin{array}{l}\mathrm{EN} \\
26\end{array}$ & $12697-$ & 4022 & $3600-7000$ & $\operatorname{Smin} 3600$ \\
\hline 9 & Bulk Density & {$\left[\mathrm{kg} / \mathrm{m}^{3}\right]$} & $\begin{array}{ll}\text { EN } & 1 \\
6 & \end{array}$ & $12697-$ & 2702 & - & - \\
\hline 10 & $\begin{array}{l}\text { Maximum } \\
\text { Bulk Density }\end{array}$ & {$\left[\mathrm{kg} / \mathrm{m}^{3}\right]$} & $\begin{array}{ll}\text { EN } & 1 \\
5\end{array}$ & $12697-$ & 2828 & - & - \\
\hline 11 & $\begin{array}{l}\text { Degree of } \\
\text { compaction, } \\
\text { min. }\end{array}$ & {$[\%]$} & $\mathrm{EN}$ & & 98 & 98 & Min 98 \\
\hline 12 & Stability & {$[\mathrm{kN}]$} & EN & $12697-$ & 8.8 & - & - \\
\hline 13 & Deformation & {$[\mathrm{mm}]$} & 34 & & 3.9 & - & - \\
\hline 14 & $\mathrm{~S} / \mathrm{D}$ & {$[\mathrm{kN} / \mathrm{mm}$} & & & 2.3 & - & - \\
\hline 15 & $\begin{array}{l}\text { Bitumen cont. } \\
\text { in AM }\end{array}$ & {$[\%]$} & EN 15 & 15326 & 4.5 & $6-7 \%$ & - \\
\hline
\end{tabular}

\section{Test Analyses of paved wearing course SMA - 16}

During the laying down of the wearing course SMA 16 some smooth areas were noticed after the ironing of the paved surface, even the test analysis were within the GTR requirements. These smooth areas were created as a consequence of appearance on surface of excessive amount of bitumen and polymers in the bitumen coat. see picture 1 and picture 2

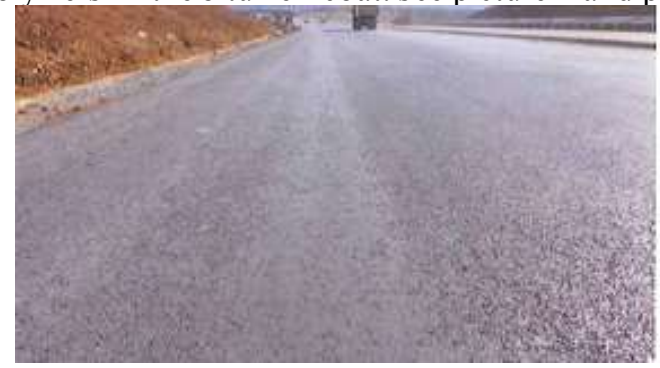

Fig. 1. Smooth areas of WC-SMA 16

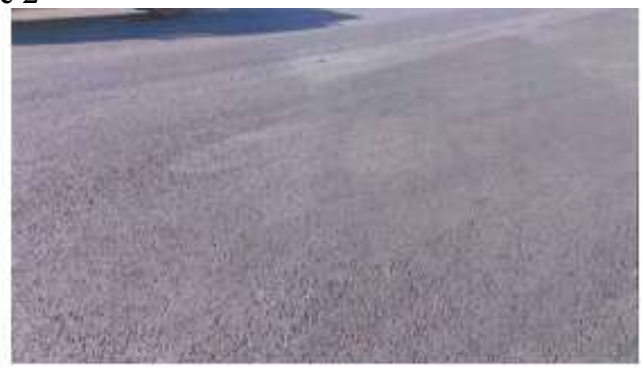

Fig. 2. Smooth areas of WC-SMA 16

Checked samples of WC - SMA 16 composition and physical mechanical properties of the hot mix asphalt meet the GTR requirements as presented at table 8, in the light of the probleme occurred of non 
uniformity of the wearing course the operator with the presence of internal control and surveillance reduced the energy of the compaction of as phalt layers. The standard compaction procedure $1 \mathrm{~S}+3 \mathrm{~V}+0.5$ $\mathrm{S}$ was reduced to $1 \mathrm{~S}+2.5 \mathrm{~V}+0.5$ and the uniformity of the wearing course was slightly improved as showned in the picture 3 and picture 4 .

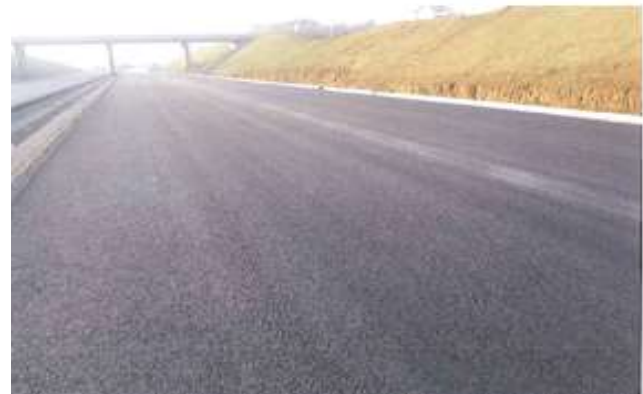

Fig 3. Uniformed Paved WC - SMA 16

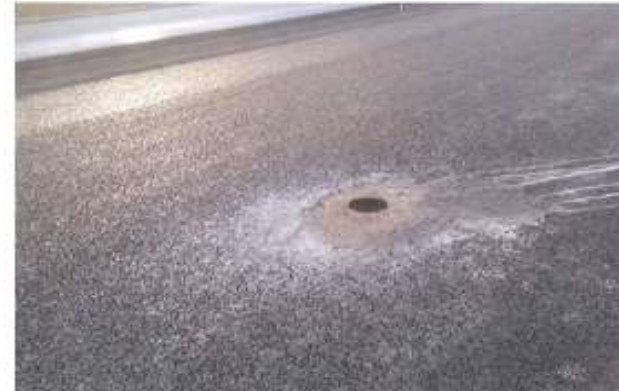

Fig 4. Uniformed Paved WC-SMA 16

surface after reduction of energy

surface after reduction of energy

it need to be stated fact that even the vibration energy was reduced, test results prove that the asphalt wearing course compaction is within the GTR parameters (general technical requirements) for road works of wearing course.

By all project stakeholders The Client, The Employer Representative and by the Contractor is accepted that for Kosovo Motorway SMA wearing course a reduced energy compaction to be used until the completion of the motorway unless the rock is changed.

\section{Conclusion:}

- Stone quality as raw material for production of granular stone material must full fill the conditions in order to be used for the as phalt pavements.

- Sometimes can be considerd stone for producing the granular material with the higher resistance on fragmentation and higher specific weight as well.

- Superpave design mix with stone granular material with higher spefic weight than optimum stones requires less bitumen in the design mix.

- Designers who prepare the superpave design mix with stone grit not fulfilling the standard conditions need to compare gain results with the design mix used in any previous project as reference,

- SMA design mix used in Kosovo motorways requires less energy for the compaction than reference design mix,

- With increase of weight with specific percentage the contractor must decrease the unit price for that percentage because the asphalt wearing course mass is same for two different stone materials even the specific weights change.

\section{References}

1. AASHTO Guide for Design of Pavement Structures 1993,

2. Hot - Mix Asphalt paving Handbook 2000, US Army Corps of Engineers, 
3. Druschner, L; Schafer, V; „Stone Mastic Asphalt” German Asphalt Associations - English Version 2005,

4. Ramljak, Z;Pejnovic,V; „Possibilities for using the carbonate stone material for binder courses

5. on asphalt pavement of all traffic loading categories", Construction Almanac, Union of Construction Engineers and technicians of Yugoslavia, Belgrade (1983), pages 337-340.

6. Test Report No MD (BEGP - KMP) -08-03/2011, (WC - SMA 16), Ramtech October 2011, Zagreb,

7. Test Report No 61054-20-2739/11 Resistance to degradation of crushed rock aggregate from MiM Golesh by compaction of Marshall Sample, Zagreb October 2011,

8. General Technical requirement for Motorway Construction, Zagreb 2011,

9. EN 12697-1;2005 Bituminous mixtures - Test method for hot mix asphalt, Binder content 